\title{
Methods for the assessment of opioid-induced hyperalgesia in the perioperative period*
}

\author{
Métodos para a avaliação da hiperalgesia induzida por opioides no período perioperatório
}

Plínio da Cunha Leal ${ }^{1}$, Rioko Kimiko Sakata²

${ }^{*}$ Received from Federal Univeristy of São Paulo, São Paulo, SP, Brazil.

\section{ABSTRACT}

BACKGROUND AND OBJECTIVES: Opioid-induced hyperalgesia is a topic not yet fully understood in terms of mechanisms, diagnosis, prevention and treatment. Thus, it seems of great importance to evaluate this phenomenon that negatively affects the treatment of pain. The purpose of this study was to describe what tools to use to evaluate perioperative hyperalgesia.

CONTENTS: Several methods have been suggested to evaluate opioid-induced hyperalgesia, such as measure of pain intensity, opioid consumption, and evaluation of secondary hyperalgesia with algometer and Von Frey monofilaments. The measurement of some substances, such as cytokines, glutamate, and dynorphin has also been used.

CONCLUSION: There are several ways to evaluate opioidinduced hiperalgesia, easily reproducible tests should be chosen and which have also been described in previous studies.

Keywords: Analgesic opioid, Evaluation, Hyperalgesia, Pain.

\section{RESUMO}

JUSTIFICATIVA E OBJETIVOS: A hiperalgesia induzida pelo opioide é um tema ainda não totalmente esclarecido do ponto de vista dos mecanismos, do diagnóstico, da prevenção e do tratamento. Assim, parece de grande importância a avaliação desse fenômeno que afeta de maneira negativa o tratamento da dor. O objetivo deste estudo foi descrever quais instrumentos utilizar para avaliar a hiperalgesia perioperatória.

1. Hospital São Domingos, Department of Anesthesiology, Pain Sector, São Luís, MA, Brazil. 2. Federal University of São Paulo, Discipline of Anesthesiology, Pain and Intensive Care, Pain Sector, São Paulo, SP, Brazil.

Submitted in June 17, 2014.

Accepted for publication in October 23, 2014.

Conflict of interests: none - Sponsoring sources: CAPES FAPESP 2009/53335-4.

Correspondence to:

Plinio da Cunha Leal

Rua Botucatu, 593, Vila Clementino

18608-226 São Paulo, SP, Brasil.

E-mail: pliniocunhaleal@hotmail.com

(C) Sociedade Brasileira para o Estudo da Dor
CONTEÚDO: Vários métodos têm sido indicados para avaliar hiperalgesia induzida pelo opioide, tais como medida da intensidade da dor, consumo de opioide, e avaliação da hiperalgesia secundária com algômetro e monofilamentos de Von Frey. A dosagem de certas substâncias, como citocinas, glutamato e dinorfina, também tem sido utilizada.

CONCLUSÁO: Existem diversas maneiras de avaliar a hiperalgesia induzida pelo opioide; portanto devem ser escolhidos testes de fácil reprodutibilidade e que também foram descritos em estudos anteriores.

Descritores: Analgésico opioide, Avaliação, Dor, Hiperalgesia.

\section{INTRODUCTION}

Opioid-induced hyperalgesia $(\mathrm{OIH})$ is a subject not totally explained in terms of mechanisms, diagnosis, prevention and management. There is no report in the literature on the incidence of OIH; however this effect may be present in all individuals under opioids ${ }^{1-3}$.

This is a phenomenon present both during prolonged administration ${ }^{1,3,4}$ and during short periods of time ${ }^{2}$.

Different methods have been indicated to evaluate $\mathrm{OIH}$, such as pain intensity measurement, opioid consumption and evaluation of secondary hyperalgesia with algometer and Von Frey monofilaments ${ }^{5}$. So it is critical to understand hyperalgesia evaluation methods, although many of them are still being used just in studies and patients at high risk of developing OIH.

This study aimed at describing which tools should be used to evaluate perioperative hyperalgesia.

\section{PAIN INTENSITY}

Pain measurement is a challenge due pain subjectivity and complexity. Pain intensity may be measured with one-dimensional or multidimensional scales. One-dimensional scales are: numerical scale, using scores from zero to 10 or from zero to 100; verbal scale, using categories such as no pain, mild, moderate and severe pain; and visual analog scale, using a straight line where one edge represents no pain and the opposite edge the worst imaginable pain, and patients mark where they believe is current intensity ${ }^{6}$.

According to current pain concepts, nociceptive stimuli are modulated at spinal cord level before reaching supra-segmen- 
tal structures and pain is no longer seen as a direct response exclusively related to tissue injury extension. So, there are different pain dimensions: sensory-discriminative; affectiveemotional; autonomic reactions; and evaluative, being those scales called multidimensional scales, such as McGill pain questionnaire $^{7}$ (MPQ).

MPQ was developed in 1975 by Melzack in the McGill University, Montreal, Canada, aiming at supplying qualitative pain measurements which could be statistically analyzed. This is one of the most widely used questionnaires in the clinical practice and evaluates sensory, affective, temporal and miscellaneous qualities of pain, in addition to evaluating pain intensity. So it has well-established validity and reliability indices, in addition to discriminative power among different pain components ${ }^{7}$.

\section{ADDITIONAL ANALGESIA}

For the most adequate postoperative analgesic dose quantification, the most common is analgesic consumption by means of patient-controlled analgesia (PCA), being intravenous morphine the most widely used opioid (1-1.5mg bolus, 7-10 min blockade interval and 30-40mg limit in $4 \mathrm{~h}$ ), avoiding fixed and when necessary doses, which are less effective ${ }^{8}$.

\section{MONOFILAMENTS}

Hyperalgesia may be evaluated with Von Frey monofilaments 5 . Monofilaments to evaluate sensitivity started to be used in late 1800s by Von Frey, in studies on touch and pressure using horse hairs of different diameters. As from Von Frey studies, other investigators have tried to improve the technique, among them Weinstein 9 .

By analyzing Weinstein studies ${ }^{9}$, Waylett-Rendall ${ }^{10}$ and Naafs $\&$ Dagne $^{11}$ have noted the possibility of using a reduced number of monofilaments to evaluate peripheral sensitivity, without impairing results and were the first to introduce and use nylon monofilaments with diagnostic purposes and to control loss of sensory function.

Von Frey filaments have been used to determine parameters such as tactile, mechanical, nociceptive and windup thresholds $s^{5}$.

Several diseases have been evaluated with monofilaments, such as leprosy ${ }^{12}$, carpal tunnel syndrome ${ }^{13}$, brachial plexus injury $^{14}$ and post-chemotherapy ${ }^{15}$.

Although initially described to evaluate peripheral nerve injuries, investigations with monofilaments have been carried out to evaluate sensitivity threshold and pain close to surgical incision.

Sensitivity response by Von Frey monofilaments allows the evaluation of pressure on skin. Its efficacy to detect anti-hyperalgesic effect was tested in animals ${ }^{16}$ and humans ${ }^{17}$. Moreover, monofilaments allow for postoperative hyperalgesia mapping and area delimitation ${ }^{18}$.

The use of nylon filaments with constant length but increasing diameters, which tilt or bend when a certain pressure is reached, is the standard. This sensitivity evaluation procedure is sensitive and repeatable to detect peripheral nerve alterations ${ }^{19}$. Hyperalgesia may be tested with Von Frey monofilaments consisting of a set of six nylon filaments with $38 \mathrm{~mm}$ length and different diameters and weights $(0.05 \mathrm{~g} ; 0.2 \mathrm{~g} ; 2 \mathrm{~g} ; 4 \mathrm{~g} ; 10 \mathrm{~g}$ and $300 \mathrm{~g}$ ) (SORRI-BAURU') (Table 1). Each monofilament is fixed to a rod, in $90^{\circ}$ angle, and corresponds to a functional level represented by a color. Test may also be performed with a higher number of filaments; however the procedure is too lengthy and difficult.

For postoperative pain, mechanical pain threshold is evaluated before surgery and 24 hours after surgery to compare pre and postoperative sensitivity. The test starts with the lightest monofilament (green) and patients are asked to close their eyes and answer "yes" when feeling pain at monofilament touch.

Hyperalgesia is tested on the thenar eminence of the nondominant hand and on the peri-incisional region $2 \mathrm{~cm}$ apart from surgical incision. Thenar eminence is a place unrelated to surgical stimulation and where opioid hyperalgesia effect may be observed without influence of surgical incision hyperalgesia. For chronic pain, hyperalgesia may also be tested on the thenar eminence, before and after opioid administration. Different monofilaments are applied with at least 30-second intervals to decrease early responses induced by previous stimulation close to new stimulation. Three evaluations are carried out with the same monofilament. In the absence of response, the next heavier filament is applied (blue) and so on. Monofilament colors, in progressive order of application are: green, blue, violet, dark red, orange and magenta. When applying the test, patients' perception of the contact with the rods determines sensitivity of the studied region. If patients do not report pain, the heaviest filament $(300 \mathrm{~g})$ is considered pain threshold. Skin is pressed until the filament bends and pressure is maintained for approximately one and a half seconds, without allowing the filament to slide on the skin. Mechanical pain threshold is determined when patients identify two of the three stimulations as painful.

Table 1. Monofilaments

\begin{tabular}{lc}
\hline Types of monofilaments & \\
\hline Green & $0.05 \mathrm{~g}$ \\
Blue & $0.2 \mathrm{~g}$ \\
Violet & $2 \mathrm{~g}$ \\
Dark red & $4 \mathrm{~g}$ \\
Orange & $10 \mathrm{~g}$ \\
Magenta & $300 \mathrm{~g}$ \\
\hline
\end{tabular}

\section{HYPERALGESIA EXTENSION}

For postoperative pain, hyperalgesia extension is determined close to the incision. A filament from the monofilaments kit is used, depending on the selected kit and on how many grams the monofilament has, starting stimulation outside the hyperalgesia area, where no pain sensation is reported, and proceeding with stimulation at every $0.5 \mathrm{~cm}$ until surgical 
incision, in four points (upper, right lateral, left lateral and lower). The first point where patients report pain is marked. If no pain sensation is reported, stimulation ends at $0.5 \mathrm{~cm}$ from the incision.

The distance from each point to the surgical incision is measured and the sum of distances is determined ${ }^{5}$.

\section{DYNAMIC ALLODYNIA}

For postoperative pain, dynamic allodynia is evaluated with a smooth brush on the thenar eminence of the non-dominant hand and on the peri-incisional region. Allodynia is confirmed when stimulation induces obvious pain sensation ${ }^{5}$.

\section{ALGOMETER}

Mechanical pressure pain threshold on the thenar eminence of the non-dominant hand and periumbilical region may also be evaluated with algometer, tool which evaluates pressure on skin by gradually increasing $0.1 \mathrm{Kgf}_{\mathrm{gec}} \mathrm{c}^{-1}$. Evaluation may be performed by different evaluators with the same reproduction capacity; however a mean of three evaluations should be performed ${ }^{20}$.

Algometer has been used to evaluate pressure threshold in different diseases. It is used to evaluate carpal tunnel syndrome ${ }^{13}$ and other painful syndromes such as fibromyalgia, low back pain, myofascial syndrome and headache ${ }^{21-23}$.

Labor pain may be predicted by pressure threshold using the algometer ${ }^{24}$. Sensitivity threshold close to surgical incision has been also evaluated with algometer ${ }^{5,25}$.

Although widely used to evaluate sensitivity threshold in different clinical situations, one should take into consideration other characteristics, such as gender ${ }^{26}$, age and weight ${ }^{27}$, in addition to emotional characteristics ${ }^{28}$.

\section{OTHER SENSORY TESTS}

Other sensory tests (heat, cold, vibration and electric stimulation) may be used to observe different sensitivity thresholds and to prove the effect of the studied drug. However these procedures cannot be reproduced due to the long time needed to perform them (>30 minutes), in addition to being difficult to be understood by patients ${ }^{29}$.

\section{CYTOKINES DOSAGE}

Pain is intrinsically related to the immune system in such a way that it is not totally understood whether nociception block decreases pro-inflammatory cytokines production or whether decreased pro-inflammatory cytokines production results in less severe pain ${ }^{30}$.

Cytokines may produce their effects locally or, when excessively produced, may act as hormones, reaching blood flow. So, they are responsible for local or systemic responses, generating immune, metabolic, hemodynamic, endocrine and neural changes ${ }^{31}$.
These molecules may trigger short and long term effects, and may lead to chronic hyperexcitability and changes on nociceptors expression, abnormal processing of painful stimulations and exacerbation of painful processes ${ }^{32}$.

After tissue injury, first cytokines to be formed are IL- $1 \beta$ and TNF- $\alpha$, which directly act on specific receptors of sensory neurons and lead to the synthesis of other cytokines, which in turn induce glial cells proliferation in the central nervous system with the release of pro-inflammatory cytokines ${ }^{30,32,33}$. Cytokines are related to OIH and may act as OIH markers. Opioids are associated to increased pro-inflammatory cytokines, which indirectly modulate pain by releasing substances such as nitric oxide, oxygen free radicals, prostaglandins, microglia excitatory amino acids and astrocytes. With this, there is $\mathrm{N}$-methyl-D-aspartate (NMDA) receptors activation, inducing peripheral and central sensitization and hyperalgesia ${ }^{1,3}$.

Cytokines are released between $2 \mathrm{~h}$ and $4 \mathrm{~h}$ after tissue injury, and magnitude depends on trauma extension ${ }^{33}$. First cytokines released after tissue injury are TNF- $\alpha$ and IL-1. However IL-6 is considered the most relevant marker of tissue injury level during surgery ${ }^{34}$.

After injury, IL-6 plasma concentrations are detectable within 60 minutes, with peak between $4 \mathrm{~h}$ and $6 \mathrm{~h}$ and may persist for 10 days.

IL-8 production is stimulated by IL-6, with similar action peak, being described as a marker of different clinical conditions, among them postoperative pain ${ }^{35}$.

Anti-inflammatory cytokines are molecules regulating inflammatory cytokines production, thus acting on immune response regulation. There are several anti-inflammatory cytokines, such as IL-1 receptor inhibitor, IL-4, IL-10 and IL$13^{35,36}$. However, IL-10 is the primary anti-inflammatory cytokine, acting by inhibiting the production of IL-1, IL- 6 and TNF- $\alpha^{30}$. Acute IL-10 administration suppresses pain facilitation in different animal models ${ }^{36}$ and chronic pain patients have low IL-4 and IL-10 levels ${ }^{37}$.

\section{OTHER MARKERS}

NMDA receptors activation by glutamate is implied in $\mathrm{OIH}$ mechanisms $s^{1,2}$. Increased glutamate release in spinal cord dorsal horn and sustained increase of NMDA receptors response seem to be the primary OIH mechanisms ${ }^{38,39}$.

$\mathrm{OIH}$ has been associated to increased cholecystokinin, which is a peptide related to calcitonin gene (CGRP), substance-P and nociceptin in ventromedial rostral spinal cord ${ }^{40}$.

A different mechanism involves facilitator descending pathways which are mediated via opioids in on cells located in the ventromedial rostral spinal cord ${ }^{40}$. Exposure to morphine causes neuroplastic ventromedial rostral spinal cord changes, descending facilitation via on cells, with increased dynorphin ${ }^{3}$. Prostaglandins and chemokines may also be relevant for the development of $\mathrm{OIH}^{1,3}$. There is increased fos-C protein in spinal cord sensory neurons ${ }^{1,3}$. Nitric oxide synthase and hemoxigenase systems may be involved in $\mathrm{OIH}^{1}$. Other possible mechanism would be decreased glicinergic inhibitory control ${ }^{1}$. 


\section{CONCLUSION}

There are many ways to evaluate $\mathrm{OIH}$, however one should select tests which are easy to reproduce and which have also been described in previous studies, in addition to using more than one evaluation method.

\section{REFERENCES}

1. Angst MS, Clark JD. Opioid-induced hyperalgesia: a quantitative systematic review. Anesthesiology. 2006;104(3):570-87.

2. DuPen A, Shen D, Ersek M. Mechanisms of opioid-induced tolerance and hyperalgesia. Pain Manag Nurs. 2007;8(3):113-21.

3. Chu LF, Angst MS, Clark D. Opioid-induced hyperalgesia in humans: molecular mechanisms and clinical considerations. Clin J Pain. 2008;24(6):479-96.

4. Guignard B, Bossard AE, Coste C, Sessler DI, Lebrault C, Alfonsi P, et al. Acute opioid tolerance: intraoperative remifentanil increases postoperative pain and morphine requirement. Anesthesiology. 2000;93(2):409-17.

5. Joly V, Richebe P, Guignard B, Fletcher D, Maurette P, Sessler DI, et al. Remifentanil-induced postoperative hyperalgesia and its prevention with small-dose ketamine. Anesthesiology. 2005;103(1):147-55.

6. Sakata RK, Issy AM. Guias de Medicina Ambulatorial e Hospitalar da Unifesp. 2a ed. Săo Paulo: Manole; 2008.

7. Melzack R, Torgerson WS. On the language of pain. Anesthesiology. 1971;34(1):50-9.

8. Scherpereel P. Patient-controlled analgesia. Ann Fr Anesth Reanim. 1991;10(3):269-83.

9. Weinstein S. Fifty years of somatosensory research: from the Semmes-Weinstein monofilaments to the Weinstein Enhanced Sensory Test. J Hand Ther. 1993;6(1):11-22.

10. Waylett-Rendall J. Sensibility evaluation and rehabilitation. Orthop Clin North Am. 1988;19(1):43-56.

11. Naafs B, Dagne T. Sensory testing: a sensitive method in the follow-up of nerve involvement. Int J Lepr Other Mycobact Dis. 1977;45(4):364-8.

12. Villarroel MF, Orsini MB, Lima RC, Antunes CM. Comparative study of the cutaneous sensation of leprosy-suspected lesions using Semmes-Weinstein monofilaments and quantitative thermal testing. Lepr Rev. 2007;78(2):102-9.

13. Barbosa RI, da Silva Rodrigues EK, Tamanini G, Marcolino AM, Elui VM, de Jesus Guirro RR, et al. Effectiveness of low-level laser therapy for patients with carpal tunnel syndrome: design of a randomized single-blinded controlled trial. BMC Musculoskelet Disord. 2012;13:248.

14. Bertelli JA, Ghizoni MF. Grafting the C5 root to the musculocutaneous nerve partially restores hand sensation in complete palsies of the brachial plexus. Neurosurgery. 2012;71(2):259-63.

15. Boyette-Davis JA, Eng C, Wang XS, Cleeland CS, Wendelschafer-Crabb G, Kennedy WR, et al. Subclinical peripheral neuropathy is a common finding in colorectal cancer patients prior to chemotherapy. Clin Cancer Res. 2012;18(11):3180-7.

16. Zahn PK, Brennan TJ. Lack of effect of intrathecally administered N-methyl-D-aspartate receptor antagonists in a rat model for postoperative pain. Anesthesiology. 1998;88(1):143-56

17. Pedersen JL, Galle TS, Kehlet H. Peripheral analgesic effects of ketamine in acute inflammatory pain. Anesthesiology. 1998;89(1):58-66

18. Ilkjaer S, Bach LF, Nielsen PA, Wernberg M, Dahl JB. Effect of preoperative oral dextromethorphan on immediate and late postoperative pain and hyperalgesia after total abdominal hysterectomy. Pain. 2000;86(1-2):19-24.

19. Bell-Krotoski J, Tomancik E. The repeatability of testing with Semmes -Weinstein monofilaments. J Hand Surg. 1987;12(1):155-61.

20. Chesterton LS, Sim J, Wright CC, Foster NE. Interrater reliability of algometry in measuring pressure pain thresholds in healthy humans, using multiple raters. Clin J Pain. 2007;23(9):760-6.

21. Cathcart S, Winefield AH, Lushington K, Rolan P. Noxious inhibition of temporal summation is impaired in chronic tension-type headache. Headache. 2010;50(3):403-12.

22. Öz S, Gökçen-Röhlig B, Saruhanoglu A, Tuncer EB. Management of myofascial pain: low-level laser therapy versus occlusal splints. J Craniofac Surg. 2010;21(6):1722-8.

23. Lee YC, Lu B, Edwards RR, Wasan AD, Nassikas NJ, Clauw DJ, et al. The role of sleep problems in central pain processing in rheumatoid arthritis. Arthritis Rheum. 2013;65(1):59-68

24. Carvalho B, Zheng M, Aiono-Le Tagaloa L. Evaluation of experimental pain tests to predict labor pain and epidural analgesic consumption. $\mathrm{Br} \mathrm{J}$ Anaesth. 2013;110(4):600-6.

25. Tuncer S, Yalçin N, Reisli R, Alper Y. The effects of lornoxicam in preventing remifentanil-induced postoperative hyperalgesia. Agri. 2009;21(4):161-7.

26. Chesterton LS, Barlas P, Foster NE, Baxter GD, Wright CC. Gender differences in pressure pain threshold in healthy humans. Pain. 2003;101(3):259-66.

27. Janczak AM, Ranheim B, Fosse TK, Hild S, Nordgreen J, Moe RO, et al. Factors affecting mechanical (nociceptive) thresholds in piglets. Vet Anaesth Analg. 2012;39(6):628-35

28. Pollatos O, Füstös J, Critchley HD. On the generalized embodiment of pain: how interoceptive sensitivity modulates cutaneous pain perception. Pain. 2012;153(8):1680-6.

29. Schmidt S, Bethge C, Förster MH, Schäfer M. Enhanced postoperative sensitivity to painful pressure stimulation after intraoperative high dose remifentanil in patients without significant surgical site pain. Clin J Pain. 2007;23(7):605-11.

30. Shavit Y, Fridel K, Beilin B. Postoperative pain management and proinflammatory cytokines: animal and human studies. J Neuroimmune Pharmacol 2006;1(4):443-51.

31. Watkins LR, Hutchinson MR, Johnston IN, Maier SF. Glia: novel counter-regulators of opioid analgesia. Trends Neurosci. 2005;28(12):661-9.

32. Obata H, Eisenach JC, Hussain H, Bynum T, Vincler M. Spinal glial activation contributes to postoperative mechanical hypersensitivity in the rat. J Pain. 2006;7(11):816-22.

33. Naito Y, Tamai S, Shingu K, Shindo K, Matsui T, Segawa H, et al. Responses of plasma adrenocorticotropic hormone, cortisol, and cytokines during and after upper abdominal surgery. Anesthesiology. 1992;77(3):426-31.

34. Gebhard F, Pfetsch H, Steinbach G, Strecker W, Kinzl L, Brückner UB. Is interleukin 6 an early marker of injury severity following major trauma in humans? Arch Surg, 2000;135(3):291-5.

35. Zhang JM, An J. Cytokines, inflammation, and pain. Int Anesthesiol Clin. 2007;45(2):27-37

36. Wieseler-Frank J, Maier SF, Watkins LR. Glial activation and pathological pain. Neurochem Int. 2004;45(2-3):389-95.

37. Uçeyler N, Valenza R, Stock M, Schedel R, Sprotte G, Sommer C. Reduced levels of antiinflammatory cytokines in patients with chronic widespread pain. Arthritis Rheum. 2006;54(8):2656-64.

38. Célèrier E, Rivat C, Jun Y, Laulin JP, Larcher A, Reynier P, et al. Long-lasting hyperalgesia induced by fentanyl in rats: preventive effect of ketamine. Anesthesiology. 2000;92(2):465-72.

39. Mao J. Opioid-induced abnormal pain sensitivity: implications in clinical opioid therapy. Pain. 2002;100(3):213-7.

40. Gebhart GF. Descending modulation of pain. Neurosci Biobehav Rev. 2004;27(8):729-37. 